\title{
PERANAN PENGGUNAAN MEDIA FILM PADA PROSES PEMBELAJARAN PKn DALAM MENGEMBANGKAN SIKAP NASIONALISME SISWA \\ (Studi Deskriptif Analisis Pada Siswa Kelas X SMA Negeri 11 Palembang)
}

\author{
Wendy Anugrah Octavian, Prodi Pendidikan Kewarganegaraan, SPs, UPI
}

\begin{abstract}
ABSTRAK
Dengan adanya era globalisasi membawa paradigma baru bahwa masyarakat saat ini adalah masyarakat global bukan masyarakat nasional ataupun lokal, sehingga secara perlahan tetapai pasti akan mengkaburkan nilai-nilai nasionalisme yang telah terbangun bertahun tahun lamanya, bahkan tak jarang akan menghadirkan konflik antar masyarakat. Pendidikan kewarganegaraan merupakan solusi untuk mengatasi kemerosotan dari sikap nasionalisme warganegara muda Indonesia. Pendidikan kewarganegaraan yang merupakan wadah pendidikan yang bertujuan mendidik warganegara muda Indonesia memiliki sikap nasionalisme yang tinggi terhadap negaranya. Perlu adanya penerapan yang inovatif dalam pelaksanaan pembelajaran yaitu dengan menggunakan media film. Film yang merupakan refleksi dari gambar yang bergerak dan bersuara memiliki keunggulan dalam penerapannya pada pembelajaran di kelas. Penerapan media film pada proses pelaksanaan pembelajaran dikelas dapat membantu siswa dalam memahami dan merasakan keadaan yang sebenarnya dari sebuah kehidupan.
\end{abstract}

Kata kunci: media film, pembelajaran PKn, Sikap nasionalisme.

\section{PENDAHULUAN}

Nasionalisme dapat dipahami dari sudut pandang antropologi dan politik. Dalam dimensi antropologi, nasionalisme dipandang sebagai sistem budaya yang mencakup kesetiaan, komitmen, emosi, perasaan kepada bangsa dan negara, dan rasa memiliki bangsa dan negara itu. Dalam dimensi ini, Benedict Anderson mengatakan bahwa nation (bangsa) adalah suatu komunitas politik yang terbatas dan beradaulat yang dibayangkan (imagined communities). Komunitas politik itu dikatakan sebagai imagined communities sebab suatu komunitas tidak mungkin mengenal seluruh warganya, tidak mungkin saling bertemu, atau saling mendengar. Akan tetapi, mereka memiliki gambaran atau bayangan yang sama tentang komunitas mereka. Suatu bangsa dapat terbentuk, jika sejumlah warga dalam suatu komunitas mau menetapkan diri sebagai suatu bangsa yang mereka angankan atau bayangkan (Anderson dalam Yuliati, 2009: 1). Karena komitmen dan keinginan untuk mengikatkan diri dalam komunitas bangsa ini, dapat muncul kesetiaan yang tinggi pada nation state (negara kebangsaan). Bahkan, banyak warga suatu negara kebangsaan rela mengorbankan jiwaraga untuk membela bangsa dan negara mereka. Senada dengan Benedict Anderson, Ernest Renan mengatakan bahwa unsur utama dalam pembentukan suatu bangsa adalah le desir de'etre ensemble (keinginan untuk bersatu). (Abdullah dalam Yuliati, 2009: 1). Abdoel Moeis, seorang tokoh Sarekat Islam, pada tahun 1917 telah mengartikan nasionalisme sebagai perasaan cinta kepada bangsa dan tanah air, yang diungkapkannya pada harian Sinar Djawa, 25 Oktober 1917 sebagai berikut: Kalaoe kita mengingat akan nasib boeroeknja tanah air dan bangsa kita, jang beratoes tahoen selaloe berada dalam koengkoengan orang lain sadja, maka brdebarlah dada, timboellah soeatoe perasaan jang menggojang segala oerat saraf kita, perasaan kasihan kepada bangsa dan tanah air itoe (Sinar Djawa, 25 Oktober 1917 dalam Yuliati, 2009:1).

Dalam dimensi politik, nasionalisme merupakan ideologi yang meyakini bahwa 
kesetiaan tertinggi individu harus diserahkan kepada negara kebangsaan, yaitu suatu negara yang penduduknya memiliki hak dan kewajiban sama serta mau mengikatkan dirinya dalam suatu negara (Kohn, Romein dalam Yuliati, 2009: 2). Demikian juga Soekarno, presiden pertama Indonesia, mengatakan bahwa bangsa adalah sebuah konstruksi yang dihasilkan oleh sebuah visi yang diperjuangkan, Dalam pengertian politik ini, prinsip-prinsip utama dalam nasionalisme adalah kebebasan, kesatuan, keadilan, dan kepribadian yang menjadi orientasi kehidupan kolektif suatu kelompok untuk mencapai tujuan politik, yaitu negara nasional (Kartodirdjo dalam Yuliati, 2009: 2). Sebagai doktrin politik, nasionalisme merupakan basis serta pembenaran ideologis bagi setiap bangsa di dunia untuk mengorganisasi diri dalam entitas-entitas yang bebas atau otonom, dan entitas itu mengambil bentuk negara nasional yang merdeka (Riff dalam Yuliati, 2009: 2).

Selain itu, nasionalisme tidak lepas dari unsur konsep nation, nasional, isme. Ketiga unsur ini memiliki arti yang berbeda, yang sama berbeda dengan definisi nasionalisme. Nation berarti kumpulan penduduk dari suatu propinsi, suatu negeri atau suatu kerajaan. Adapula yang mengartikan suatu negara atau badan politik yang mengakui suatu pusat pemerintahan bersama dan juga wilayah yang dikuasai oleh negara tersebut serta penduduk yang ada didalamnya, atau lebih mudahnya dikatakan sebagai bangsa. Menurut Kamus Besar Bahasa Indonesia, nasional berarti bersifat kebangsaan; berkenaan/berasal dari bangsa sendiri; meliputi suatu bangsa. Nasionalisme lebih merupakan paham meskipun memiliki akhiran-isme. Hal ini pun diakui dalam Kamus Besar Bahasa Indonesia bahwa nasionalisme bermakna paham (ajaran) untuk mencintai bangsa dan negara sendiri.

Nasionalisme bukan merupakan ideologi karena ideologi lebih bersifat mendalam. Ideologi adalah pemikiran yang mendasar dan menyeluruh tentang manusia, alam dan kehidupan yang memunculkan aturan atau sistem operasional dalam menjalankan berbagai aspek kehidupan. Dengan definisi seperti ini maka hanya dapat ditemukan 3 definisi bersifat murni yaitu Liberalisme-Kapitalisme, Sosialisme-Komunisme dan Islam. Sedangkan yang lain merupakan ideologi yang bersifat mencampur, memadukan dan mengkompromikan seperti halnya ide tentang Third Way yang digulirkan Anthony Giddens yang merupakan kompromi antara Liberalisme dan Sosialisme (Dewi, 2008).

Nasionalisme secara konseptual memiliki makna yang beragam. Ada yang mengartikan nasionalisme sebagai (1) kulturnation dan staatnation; (2) loyalitas (etnis dan nasional) dan keinginan menegakkan negara; (3) identitas budaya dan bahasa, dan sebagainya (Dewi, 2008).

Pada konteks kehidupan berbangsa dan bernegara bangsa Indonesia mengenal Negara Kesatuan Republik Indonesia (NKRI) sebagai indentitas nasional. Indonesia adalah masyarakat yang menghuni kepulauan yang sambung menyambung dari Sabang sampai Merauke. Oleh karena itu bangsa Indonesia adalah bangsa yang berdasarkan kesadaran moral dan perjanjian suci antar masyarakat untuk mengakui plural yang sebagai sarana untuk bersatu (Sukadi dalam).

Secara budaya yang dimaksud identitas nasional adalah jati diri yang melekat pada seseorang atau sesuatu yang bisa membedakannya. Karakteristik yang terdapat dalam identitas nasional itu, suatu negara mampu menampilkan watak, karakteristik kebudayaan dan memperkuat rasa kebangsaan. Dan identitas nasional juga bisa dikatakan sebagai jati diri yang menjadi slogan-slogan kibaran berdera kehidupan.

Kedudukannya sangat penting dan strategis sehingga identitas nasional harus dimiliki setiap bangsa, karena tanpa identitas nasional suatu bangsa akan terombang - ambing tak memiliki pijakan yang kuat.Namun kenyataannya sekarang fenomena yang terjadi dimasyarakat telah terjadi pengikisan identitas nasional bangsa. Banyak hal yang menjadi penyebabnya seperti dengan adanya pengaruh yang timbul dari pihak luar. Budaya-budaya barat yang masuk ke Indonesia begitu cepat diserap oleh setiap lapisan masyrakat. Berbagai perilaku dan penampilan gaya bahasa, pola pikir dan mode pakaian yang dipengaruhi oleh 
budaya barat. Memang semua kebudayaan, pola pikir dan mode yang datang dari luar tidak semuanya negatif dan berdampak buruk pada identitas nasional bangsa, tetapi yang terjadi adalah kecendrungan konsumtif terhadap apa yang datang dari luar dan secara tidak disadari akan menggerus rasa nasionalisme dan kebangsaan masyarakat khususnya generasi muda.

Bersamaan dengan itu rasa nasionalisme pun terkikis, maka persoalan rasa kebangsaan dan nasionalisme sebetulnya adalah masalah yang tidak sederhana namun sedemikian komplek. Disamping itu dengan adanya era globalisasi membawa paradigma baru bahwa masyarakat saat ini adalah masyarakat global bukan masyarakat nasional ataupun lokal, sehingga secara perlahan tetapai pasti akan mengkaburkan nilai - nilai nasionalisme yang telah terbangun bertahun tahun lamanya, bahkan tak jarang akan menghadirkan konflik antar masyarakat. Naisbit sebagaimana dikutip Yasa (2011) mengatakan bahwa era globalisasi akan memunculkan citra global dengan budaya global yang langsung menentang budaya lokal. Revolusi informasi dan komunikasi sebagai dampak langsung dari kemajuan IPTEK telah menghilangkan batasan-batasan region dan kewilayahan ,sehingga bagi masyarakat tertentu, kondisi ini harus disikapi dengan cepat dan komperhensif sehingga mereka tidak kehilangan jadi diri bangsa dan negaranya (Schement, 2002 ; Jannees, 2001 dalam Yasa, 2011).

Tantangan bagi nasionalisme lahir seiring dengan semakin modernnya kehidupan manusia dimana jarak bukan lagi suatu halangan, dimana media telekomunikasi telah menyatukan semua lapisan masyarakat menjadi suatu global village. Diaspora (persebaran) globalisasi yang pesat merupakan penyebab utama kemerosotan rasa nasionalisme, (Hendrastomo, 2007:1). Berdasarkan hasil wawancara awal peneliti dengan guru bahwa sikap nasionalisme siswa kelas X MIA 3 sangatlah kurang atau telah terkikis oleh karena dampak arus globalisasi. Guru berkata bahwa, siswa sering kali mengobrol ketika pelaksanaan upacara bendera dan sering tidak menghargai dan memperdulikan antara satu sama lain.
Permasalahan tersebut telah dialami oleh siswa yang bernama Ayu dia berkata bahwa sebelum pembelajaran dengan menggunakan fim ini mengobrol ketika upacara bendera berlangsung, namun setelah guru menerapkan media film dalam proses pembelajaran Ayu merasa tersentuh hatinya melihat apa yang dilakukan oleh pemeran film tersebut sehingga Dia melakukan upacara bendera dengan baik dan tertib. Oleh sebab itu, guru menggunakan film pada proses pembelajaran PKn guna mengembangkan sikap nasionalisme siswa.

Salah satu yang dapat dilakukan untuk mengembangkan sikap dan jiwa nasionalisme warganegara muda Indonesia melalui Pendidikan Kewarganegaraan yang merupakan salah satu hal penting dalam mengembangkan sikap nasionalisme individu. Dalam menghadapi globalisasi dan menatap masa depan untuk mengisi kemerdekaan, memerlukan perjuangan non fisik sesuai bidang profesi masing-masing. Perjuangan non fisik sesuai bidang profesi masing-masing tersebut memerlukan sarana kegiatan pendidikan bagi setiap warga negara Indonesia pada umumnya dan mahasiswa sebagai calon cendikiawan pada khususnya, yaitu melalui Pendidikan Kewaranegaraan.

Pendidikan Kewarganegaraan (PKn) berupaya mengantarkan warganegara Indonesia menjadi ilmuwan dan profesional yang memiliki rasa kebangsaan dan cinta tanah air, menjadi warga negara demokratis yang berkeadaban, yang memiliki daya saing, berdisiplin, dan berpartisipasi aktif dalam membangun kehidupan yang damai berdasarkan sistem nilai Pancasila. PKn berupaya menanamkan sikap kepada warga negara Indonesia umumnya dan generasi muda bangsa khususnya agar, memiliki wawasan dan kesadaran kebangsaan dan rasa cinta tanah air sebagai perwujudan warga negara Indonesia yang bertanggung jawab atas kelangsungan hidup bangsa dan negara, memiliki wawasan dan penghargaan terhadap keanekaragaman masyarakat Indonesia sehingga mampu berkomunikasi baik dalam rangka meperkuat integrasi nasional, memiliki wawasan, kesadaran dan kecakapan dalam melaksanakan hak, kewajiban, tanggung jawab dan peran sertanya sebagai warga negara yang cerdas, trampil dan berkarakter, memiliki 
kesadaran dan penghormatan terhadap hak-hak dasar manusia serta kewajiban dasar manusia sehingga mampu memperlakukan warga negara secara adil dan tidak diskriminatif, berpartisipasi aktif membangun masyarakat Indonesia yang demokratis dengan berlandaskan pada nilai dan budaya demokrasi yang bersumber pada Pancasila, memiliki pola sikap, pola pikir dan pola perilaku yang mendukung ketahanan nasional Indonesia serta mampu menyesuaikan dirinya dengan tuntutan perkembangan zaman demi kemajuan bangsa. Untuk dapat mewujudkan upaya-upaya tersebut maka diperlukan pendekatan pembelajaran yang inovatif dalam proses pembelajaran PKn yaitu melalui media.

Miarso sebagaimana dikutip Sapriya (2012:172) menyatakan bahwa media adalah segala sesuatu yang dapat dipergunakan untuk menyalurkan pesan yg dapat merangsang pikiran, perasaan, perhatian, dan kemauan siswa untuk belajar. Penggunaan dari media dalam proses pembelajaran adalah untuk dapat menyampaikan informasi yang dapat didengar (audio) dan dapat dilihat (visual), sehingga dapat mendeskripsikan prinsip, konsep, proses atau prosedur yang bersifat abstrak dan tidak lengkap menjadi lebih jelas dan lengkap. Terdapat berbagai jenis media belajar, diantaranya:

1. Media Visual : grafik, diagram, chart, bagan, poster, kartun, komik

2. Media Audial : radio, tape recorder, laboratorium bahasa, dan sejenisnya

3. Projected still media : slide; over head projektor (OHP), in focus dan sejenisnya

4. Projected motion media : film, televisi, video (VCD, DVD, VTR), komputer dan sejenisnya.

Materi Pendidikan Kewarganegaraan sangat berkaitan dengan peristiwa-peristiwa aktual dinamika politik dan ketatanegaraan yang sedang berubah. Peristiwa-peristiwa tersebut seyogianya dikaitkan dengan proses pembelajaran sesuai dengan materi pokok yang sedang dibahas. Dalam kaitan ini, media televisi, film, tape recorder, video recorder, dan manusia sebagai model (tokoh) sangatlah membantu keberhasilan proses pembelajaran (Sapriya, 2012:175).
Pada penelitian ini media yang dimaksud ialah media film. Film memberikan sumbangan yang besar bagi pembelajaran Pendidikan Kewarganegaraan. Film memberikan kepada siswa pengalaman belajar dan dapat membantu menampilkan waktu berabad-abad (film sejarah atau peristiwa bersejarah) dan tempat yang berjarak ribuan kilometer di mana siswa dapat melihat tempat, orang, peristiwa yang tidak mungkin dilihatnya dengan cara lain. (Sapriya, 2012:187). Pada penelitian jenis film yang akan digunakan ialah film yang berjenis dokumenter serta kontemporer. Pemilihan film dokumenter dimaksudkan untuk memberikan pemahaman bagaimana sikap nasionalisme yang ditujukan terhadap kolonial, sedangkan tujuan pemilihan film kotemporer ditujukan untuk memberikan gambaran bagaimana bentuk nasionalisme pada saat ini. Rumusan masalah dalam penelitian ini ialah "Bagaimana Peranan Penggunaan Media Film Pada Proses Pembelajaran PKn Dalam Mengembangkan Sikap Nasionalisme Siswa"?

\section{METODE PENELITIAN}

Lokasi dari penlitian ini di SMA Negeri 11 Palembang. Penelitian ini menggunakan pendekatan kualitatif dengan metode deskriptif. Penelitian kulalitatif memiliki ciri khas penyajian datanya dalam bentuk narasi, cerita mendalam atau rinci dari para responden hasil wawancara dan observasi. Perspektif dalam penelitian kualitatif dikemukakan dalam sebutan perspektif emik. Siswa, guru, dan peneliti merupakan subjek penelitian. Sumber data dari penelitian ini diperoleh dari Siswa dan guru SMA Negeri 11 Palembang. Pengumpulan data pada penelitian ini menggunakan observasi, wawancara, dan dokumentasi sedangkan data pada penelitian ini menggunakan triangulasi data.

\section{HASIL DAN PEMBAHASAN}

Sebelum melaksanakan pembelajaran dengan menggunakan media film, pada tahap perencanaan ini guru melakukan persiapan. Persiapan yang dilakukan oleh guru meliputi, persiapan pemilihan jenis film yang akan ditayangkan. Jenis film yang dipilih ditentukan berdasarkan tujuan pembelajaran yang ditentukan dan juga berdasarkan tingkat 
perkembangan karakteristik siswa. Menurut Louisell (dalam Unik Ambar Wati, 2012: 5) langkah persiapan guru menyiapkan unit pelajaran,

1. memilih film yang tepat untuk mencapai tujuan pengajaran. Pertimbangan dalam memilih film:
a. Panjangnya film
b. Tingkat rekomendasi film
c. Tahun produksi
d. Diskripsi dari film tersebut

2. Mempersiapkan kelas, audien dipersiapkan terlebih dahulu dan menjelaskan bagianbagian yang harus mendapat perhatian khusus sewaktu menonton film.

3. Langkah penyajian, dalam penyajian ini harus dipersiapkan perlengkapan yang diperlukan, antara lain: proyektor / LCD, layar, pengeras suara dan film.

4. Aktivitas lanjutan berupa tanya jawab guna mengetahui sejauh mana pemahaman siswa terhadap materi yang disajikan oleh film tersebut.

Persiapan selanjutnya yang dilakukan guru ialah menyususn perencaan pemebalajaran, penyususnan pelaksanaan pembelajaran disesuai dengan silabus. Perencaan pelaksanaan pembelajaran yang disusun oleh guru menggunakan pendekatan saintifik dengan menggunakan film sebagai media dan sumber belajar serta menerapakan metode pembelajaran yang beragam. Perencanaan merupakan kegiatan awal yang harus dilakukan setiap orang jika ingin melakukan kegiatan. Pada umumnya keberhasilan suatu program kegiatan yang dilakukan seseorang sangat ditentukan seberapa besar kualitas perencanaan yang dibuatnya. Seseorang yang melakukan kegiatan tanpa perencanaan dapat dipastikan akan cenderung mengalami kegagalan karena tidak memiliki acuan apa yang seharusnya guru lakukan dalam rangka keberhasilan kegiatan yang guru lakukan.

Pelaksanaan pembelajaran nasionalisme dengan menggunakan media film ini dilaksanakan sebanyak tiga kali pertemuan. Setiap pertemuan kecuali pertemuan ketiga ditampilkan film berjenis dokumenter pada saat proses pembelajaran berlangsung. Selain menampilkan film, pada saat proses pembelajaran pertama guru melakukan tanya jawab dengan siswa dan memberikan kesempatan kepada siswa untuk menyampaikan tanggapan mereka terhadap film yang telah ditayangkan. pada pertemuan kedua, guru menggunakan meotde diskusi setaelah penayangan film. Pada pertemuan terakhir, guru tidak menampilkan film melainkan melakukan drama sebagai tindak lanjut dari pembelajaran dengan menggunakan film, metode sandiwara ini dilakukan untuk melihat perkembangan sikap nasionalisme siswa.

Dapat diketahui bahwa pelaksanaan pembelajaran nasionalisme dengan menggunakan media film ini berlangsung dengan inovatif. Pelaksanaan pembelajaran tidak hanya dilakukan dengan menggunakan media film tapi juga menerapkan beragama pendekatan dan berbagai macam metode pembelajaran dalam pelaksanaannya. Penggunaan media film dengan beraga pendekatan dan metode dapat menciptakan pembelajaran yang aktif bagi siswa. Menurut Percipal and Ellington (dalam Ramadhan, 2010: 30), bahwa perhatian yang penuh dalam belajar dengan metode ceramah (attention spannya) makin lama makin menurun drastis. Misalnya, dalam 50 menit belajar, maka pada awal belajar attention spannya berkisar antara 12-15 menit, kemudian makin mendekati akhir pelajaran turun menjadi 3-5 menit.

Di samping itu British Audio Visual Association (dalam Siddik, 2011:7), menyatukan bahwa $75 \%$ pengetahuan diperoleh melalui indera penglihatan, $13 \%$ indera pendengaran, $6 \%$ indera sentuhan dan rabaan dan $6 \%$ indera penciuman dan lidah. Sedangkan hasil penelitian yang dilakukan oleh perusahaan SOVOCOM COMPANY di Amerika dalam Siddik (1989: 155-156), tentang kemampuan manusia dalam menyimpan pesan adalah: verbal (tulisan) 20\%, Audio saja $10 \%$, visual saja 20\%, Audio visual $50 \%$.

Tetapi kalau proses belajar hanya menggunakan methode (a) Membaca saja, maka pengetahuan yang mengendap hanya $10 \%$ (b) Mendengarkan saja pengetahuan yang mengendap hanya $20 \%$. (c) Melihat saja pengetahuan yang mengendap bisa $50 \%$. Dan (e) Mengungkapkan sendiri pengetahuan yang mengendap bisa $80 \%$. (f) Mengungkapkan 
sendiri dan mengulang pada kesempatan lain 90\% (Siddik, 2011).

Tahapan penilaian yang dilakukan guru dalam pembelajaran ialah guru memberikan tes tertulis pada siswa pada kegiatan penutup. Soal dari tes yang diberikan oleh guru berbentuk uraian dengan lima butir pertanyaan. Penilaian berupa tes tertulis ini dilakukan untuk menilai pemahaman siswa terhadp materi yang telah diajarkan. Penilaian selanjutnya yang dilakukan guru ialah menilai keatifan dan sikap siswa dalam diskusi, penilaian dilakukan dengan cara melihat bagaimana cara siswa menyampaikan argumennya ketika menjawab pertanyaan yang ada. Penilaian terakhir yang dilakukan oleh guru ialah berupa melakukan penugasan kepada siswa untuk membuat drama yang bertemakan nasionalisme.

Penilaian pada pembelajaran dengan pendekatan saintifik meliputi penilaian proses, penilaian produk, dan penilaian sikap. Penilaian pada 3 aspek tersebut dapat dijelaskan sebagai berikut.

1. Penilaian proses atau keterampilan, dilakukan melalui observasi saat siswa bekerja kelompok, bekerja individu, berdiskusi, maupun saat presentasi dengan menggunakan lembar observasi kinerja.

2. Penilaian produk berupa pemahaman konsep, prinsip, dan hukum dilakukan dengan tes tertulis.

3. Penilaian sikap, melalui observasi saat siswa bekerja kelompok, bekerja individu, berdiskusi, maupun saat presentasi dengan menggunakan lembar observasi sikap (Emi, 2012:39).

Secara garis besar alat ukur penilaian pada dasarnya dapat digolongkan menjadi dua macam, yaitu : 1) Tes; dan 2) Bukan Tes (NonTes). Pengukuran penilaian hasil belajar menggunakan instrumen/alat ukur tes untuk mengevaluasi hasil belajar aspek kognitif. Adapun pengukuran penilaian hasil belajar alat ukur non tes untuk mengevaluasi hasil belajar aspek afektif dan keterampilan motorik. Berikut ini akan dijelaskan teknik-teknik penilaian tersebut antara lain terdiri atas:

1. Tes kinerja; berbentuk tes keterampilan tertulis, tes identifikasi, tes simulasi, dan uji petik kerja. Melalui tes kinerja peserta didik diminta untuk mendemonstrasikan kinerjanya.

2. Observasi; dilakukan untuk mengum-pulkan data kualitatif dan kuantitatif sesuai dengan kompetensi yang dinilai, baik dilakukan secara formal maupun informal. Observasi formal dilakukan dengan cara menggunakan instrumen yang sudah dirancang sebelumnya, sedangkan observasi informal dilakukan tanpa menggunakan instrumen yang dirancang terlebih dahulu.

3. Penugasan; dilaksanakan dalam bentuk proyek atau tugas rumah. Proyek adalah sejumlah kegiatan yang dirancang, dilakukan, dan diselesaikan oleh peserta didik di luar kegiatan kelas dan harus dilaporkan secara tertulis maupun lisan dalam waktu tertentu. Tugas rumah adalah tugas yang harus diselesaikan peserta didik di luar kegiatan kelas, misalnya menyelesaikan tugas mendesain dan melakukan latihan mendesain berbagai jenis busana.

4. Portofolio; kumpulandokumen dan karyakarya peserta didik dalam bidang tertentu yang diorganisasikan untuk mengetahui minat, perkembangan, prestasi, dan kreativitas peserta didik.

5. Tes tertulis; dilakukan dalam bentuk tes yang jawabannya berupa pilihan dan isian. Tes yang jawabannya berupa pilihan meliputi pilihan ganda, benar salah, menjodohkan, dll. Adapun tes yang jawabannya berupa isian berbentuk isian singkat, melengkapi dan uraian.

6. Tes lisan; dilakukan melalui komunikasi langsung tatap muka antara peserta didik dengan penguji. Pertanyaan dan jawaban diberikan secara lisan dan spontan. Tes jenis ini memerlukan daftar pertanyaan dan pedoman pensekoran.

7. Jurnal; merupakan catatan pendidik selama proses pembelajaran yang berisi informasi kekuatan dan kelemahan peserta didik yang terkait dengan kinerja ataupun sikap peserta didik yang dipaparkan secara deskriptif.

8. Wawancara; dilakukan untuk memperoleh informasi secara mendalam tentang wawasan, pandangan, atau aspek kepribadian peserta didik yang jawabannya diberikan secara lisan dan spontan. 
9. Inventori; merupakan skala psikologis yang dipakai untuk mengungkap sikap, minat, dan persepsi peserta didik terhadap sesuatu objek psikologis. Inventori antara lain berupa skala Thurstone, skala Likert, atau skala berdiferensiasi semantik.

10. Penilaian diri; merupakan teknik penilaian dengan cara meminta peserta didik untuk mengemukakan kelebihan dan kekurangan dirinya dalam berbagai hal.

11. Penilaian antarteman; merupakan teknik penilaian dengan cara meminta peserta didik untuk mengemukakan kelebihan dan kekurangan temannya dalam berbagai hal, (Emi, 2012: 40)

\section{PENUTUP}

1. Pelaksanaan pembelajaran dengan menggunakan media film, pada tahap perencanaan ini guru melakukan persiapan. Persiapan yang dilakukan oleh guru meliputi, persiapan pemilihan jenis film yang akan ditayangkan. jenis yang dipilih ditentukan berdasarkan tujuan pembelajaran yang ditentukan dan juga berdasarkan tingkat perkembangan karakteristik siswa. Persiapan selanjutnya yang dilakukan guru ialah menyususn perencaan pemebalajaran, penyususnan pelaksanaan pembelajaran disesuai dengan silabus. Perencaan pelaksanaan pembeajaran yang disusun oleh guru menggunakan pendekatan saintifik dengan menggunakan film sebagai media dan sumber belajar serta menerapakan metode pembelajaran yang beragam.

2. Pelaksanaan pembelajaran nasionalisme dengan menggunakan media film ini dilaksanakan sebanyak tiga kali pertemuan. Setiap pertemuan keculai pertemuan ketiga ditampilkan film berjenis dokumenter pada saat proses pembelajaran berlangsung. Selain menampilkan film, pada saat proses pembelajaran pertama guru melakukan tanya jawab dengan siswa dan memberikan kesempatan kepada siswa untuk menyampaikan tanggapan mereka terhadap film yang telah ditayangkan. pada pertemuan kedua, guru menggunakan meotde diskusi setaelah penayangan film. Pada pertemuan terakhir, guru tidak menampilkan film melainkan melakukan drama sebagai tindak lanjut dari pembelajaran dengan menggunakan film, metode sandiwara ini dilakukan untuk melihat perkembangan sikap nasionalisme siswa.

3. Tahapan penilaian yang dilakukan guru dalam pembelajaran ialah guru memberikan tes tertulis pada siswa pada kegiatan penutup. Soal dari tes yang diberikan oleh guru berbentuk uraian dengan lima butir pertanyaan. Penilaian berupa tes tertulis ini dilakukan untuk menilai pemahaman siswa terhadp materi yang telah diajarkan. Penilaian selanjutnya yang dilakukan guru ialah menilai keatifan dan sikap siswa dalam diskusi, penilaian dilakukan dengan cara melihat bagaimana cara siswa menyampaikan argumennya ketika menjawab pertanyaan yang ada. Penilaian terakhir yang dilakukan oleh guru ialah berupa melakukan penugasan kepada siswa untuk membuat drama yang bertemakan nasionalisme.

\section{DAFTAR PUSTAKA}

Dewi, Ita Mutiara. 2008. Nasionalisme Dan Kebangkitan Dalam Teropong. Mozaik Vol.3 No. 3, Juli 2008 ISSN 1907-6126.

Dewi Yuliati. 2009. Menyibak Fajar Nasionalisme Indonesia. Makalah dipresentasikan dalam Sarasehan Sejarah Regional Daerah, Dinas Kebudayaan dan Pariwisata Provinsi Jawa Tengah, di Hotel Pondok Tingal Magelang, 23 Mei 2009.

Emi. 2012. Pengembangan Perangkat Penilaian Pembelajaran Kompetensi Tata Busana. [Tersedia Online]. http://staff.uny.ac.id/sites/default/files/PE NGEMBANGAN\%20PERANGKAT\%20 PENILAIAN\%20PEMBELAJARAN\%20 KOMPETENSI\%20TATA\%20BUSANA. pdf. Diakses Pada Tanggal 7 Mei 2014 Pukul 17:50 WIB.

Ramdhan, Dadan F. 2010. Kriteria Pemilihan Materi Pelajaran. [Tersedia

Online].http://fayyad.googlecode.com/file S/KRITERIA\%20PEMILIHAN\%20MAT ERI\%20PELAJARAN.pdf. Diakses Pada Tanggal 7 Mei 2014 Pukul 17:55 WIB.

Sapriya. 2012. Pembelajaran Pendidikan Kewarganegaraan (PKn). Jakarta: 
Direktorat Jenderal Pendidikan Islam Kementerian Agama RI.

Siddik, Muhammad. 2012. Urgensi Sumber Belajar Dalam Pendidikan. [Tersedia Online].

http://sumut.kemenag.go.id/file/file/URG EN/khvq1333968710.pdf. Diakses Pada Tanggal 7 Mei 2014 Pukul 17:46 WIB.

Wati, Unik Ambar. 2012. Pelaksanaan Pembelajaran Yang Kondusif Dan Efektif. [Tersedia Online]. http://staff.uny.ac.id/sites/default/files/PE LAKSANAAN\%20PEMBELAJARAN.p df. Diakses Pada Tanggal 7 Mei 2014 Pukul 17:48 WIB.
Yasa , I Made Sumartha. 2011. Pengembangan Alat Ukur Sikap Nasionalisme Pada Siswa Rsbi Sma Negeri 1 Gianyar Tahun Pelajaran. Jurnal Penelitian Pascasarjana Undiksha Vol 2, No 2 Tahun 2012. [Tersedia Online]. http://pasca.undiksha.ac.id/ejournal/index. php/jurnal_ep/article/download/376/168. Diakses Pada Tanggal 7 Mei 2014 Pukul 17:45 WIB. 